\title{
Perceptions of Australian marine protected area managers regarding the role, importance, and achievability of adaptation for managing the risks of climate change
}

\author{
Christopher Cvitanovic $^{1,2}, \underline{\text { Nadine A. Marshall }}^{3}, \underline{\text { Shaun K. Wilson }}^{4,5}, \underline{\text { Kirstin Dobbs }}^{6}$ and Alistair J. Hobdav $^{7}$
}

ABSTRACT. The rapid development of adaptation as a mainstream strategy for managing the risks of climate change has led to the emergence of a broad range of adaptation policies and management strategies globally. However, the success of such policies or management interventions depends on the effective integration of new scientific research into the decision-making process. Ineffective communication between scientists and environmental decision makers represents one of the key barriers limiting the integration of science into the decision-making process in many areas of natural resource management. This can be overcome by understanding the perceptions of end users, so as to identify knowledge gaps and develop improved and targeted strategies for communication and engagement. We assessed what one group of environmental decision makers, Australian marine protected area (MPA) managers, viewed as the major risks associated with climate change, and their perceptions regarding the role, importance, and achievability of adaptation for managing these risks. We also assessed what these managers perceived as the role of science in managing the risks from climate change, and identified the factors that increased their trust in scientific information. We do so by quantitatively surveying 30 MPA managers across 3 Australian management agencies. We found that although MPA managers have a very strong awareness of the range and severity of risks posed by climate change, their understanding of adaptation as an option for managing these risks is less comprehensive. We also found that although MPA managers view science as a critical source of information for informing the decision-making process, it should be considered in context with other knowledge types such as community and cultural knowledge, and be impartial, evidence based, and pragmatic in outlining policy and management recommendations that are realistically achievable.

Key Words: adaptive management; decision making; knowledge exchange; knowledge transfer; science impact; science integration; trust

\section{INTRODUCTION}

Anthropogenic climate change is widely regarded as one of the greatest threats to species and ecosystems, with adverse impacts on the goods and services upon which human welfare depends (Pereira et al. 2010, Bellard et al. 2012). In recent times, adaptation to climate change has emerged as a key topic of scientific inquiry, with a growing body of literature demonstrating the importance of adaptation for managing the now unavoidable impacts of climate change (Bassett and Fogelman 2013). The rapid development of adaptation as a mainstream strategy to manage the risks of climate change has also resulted in the emergence of a broad range of adaptation policies and management strategies, from local to global scales. The ongoing success of such policies or management interventions is dependent on the effective integration of new scientific research into the decision-making process so that management strategies can be adapted according to new and evolving information (Policansky 1998, Tomlinson and Davis 2010).

The integration of science into the decision-making process for environmental management has represented a significant challenge, and despite a significant increase in the number of applied scientific publications and identification of critical questions (e.g., Sutherland et al. 2006, Morton et al. 2009, Beger et al. 2011), an implementation gap remains (Ormerod et al. 2002, Possingham 2009). Ineffective communication of science represents one of the key barriers preventing the integration of science into the decision-making process (Policansky 1998, Weber and Word 2001), with cultural differences between scientists and decision makers identified as one of the key underlying causes (e.g., Pouyat 1999, Briggs 2006, Roux et al. 2006). Communication, however, represents an even greater challenge for issues such as climate change, which attracts significant public attention, resulting in most individuals already possessing strong perceptions and beliefs making them highly susceptible to biases (Kahan et al. 2012, Leviston and Walker 2012). Such biases may also result in decision makers misinterpreting or even refuting the information being presented, thus preventing the integration of the information into the decision-making process (CRED 2009).

Although an extensive body of literature has identified the importance of understanding the perceptions of end users to improve the communication of science (e.g., Longstaff and Yang 2008, Boissière et al. 2013, Hamm et al. 2013), the perceptions of environmental managers have seldom been quantified. Indeed, quantifying the perceptions of environmental managers in relation to climate adaptation, or the role of science for managing the impacts of climate change remains elusive. We aim to address the gap by assessing what one group of environmental managers, Australian marine protected area (MPA) managers, views as the major risks associated with climate change, and their perceptions regarding the role, importance, and achievability of adaptation for managing the risks of climate change. A secondary aim is to quantitatively assess what environmental managers perceive as the role of science for managing the risks

${ }^{1}$ Climate Adaptation Flagship, CSIRO, ${ }^{2}$ Fenner School of Environment and Society, Australian National University, ${ }^{3}$ Climate Adaptation Flagship, CSIRO, based at James Cook University, ${ }^{4}$ Marine Science Program, Department of Parks and Wildlife, Australia, ${ }^{5}$ Oceans Institute, University of Western Australia, ${ }^{6}$ Great Barrier Reef Marine Park Authority, Australia, ${ }^{7}$ Climate Adaptation Flagship, CSIRO, Tasmania 
of climate change and identify the factors affecting the trust environmental managers have in science. In doing so, we will provide important insights into how to enhance the communication of adaptation science to improve its uptake into the decision-making process.

We focused specifically on climate adaptation in relation to Australian MPA management. Marine protected areas are one of the primary policy instruments for managing marine resources (reviewed by Graham et al. 2011), however, a recent study has shown that Australian MPA managers may be unaware of the breadth of existing scientific information that they could use to inform the decision-making process (Cvitanovic et al. 2013). In such cases, it is likely that managers rely on individual experiences or other secondary sources of information when developing and implementing conservation actions in isolation from scientific evidence (Pullin et al. 2004, Cook et al. 2010, Cvitanovic et al. 2014). Using such secondary sources of information, e.g., grey literature, websites, etc., can be problematic because it is difficult to know whether the findings and their implications are evidenced-based or personal judgement based on experience (Sutherland et al. 2004). It is clear that enhancing communication and improving the uptake of science by MPA managers is critical to ensure that effective policies and programs can be implemented.

\section{METHODS}

\section{Survey design}

A combination of qualitative and quantitative research methods were used to assess the perceptions of Australian MPA decision makers about: (1) the risks of climate change to marine ecosystems; (2) the importance, role, and achievability of adaptation for managing the risks of climate change; and (3) the role of science for managing the risk of climate change, including the factors that make decisions makers trust the science being produced. First, to develop our approach, we undertook a qualitative scoping study in which we interviewed three experienced Australian MPA managers and three researchers with a publication history in MPAs and climate adaptation to understand their perceptions regarding our three focal research categories. By interviewing both managers and scientists, we were able to capture a range of opinions and elicit the main issues, as seen by both groups, as a basis for developing our final quantitative survey (Bryman 2012, Fink 2013, Marshall et al. 2013).

In total six questions formed the basis of the scoping study, and these were designed to directly explore perceptions in relation to our hypothesis/aims. These questions were: (1) what do you consider the risks associated with climate change; (2) what do you consider the role of adaptation for managing the impacts of climate change; (3) how important is adaptation for managing the risks of climate change; (4) do you think climate adaptation is achievable/feasible; (5) how important is science in managing the risks associated with climate change; and (6) what would make you trust the scientific findings? Responses to each of the scoping questions were transcribed to form the basis of the final quantitative survey.

The quantitative survey was structured to comprehend the perceptions of managers as accurately and efficiently as possible within each of the three scoping categories. All questions were posed as a statement, and respondents were asked to indicate how strongly they agreed or disagreed with each statement on a 10 point Likert scale. Using this approach, a score of 1 indicated that the participant strongly disagreed with the statement, whereas a score of 10 meant that the participant strongly agreed with the statement. This scoring range increased the sensitivity of the data, and because there was no midpoint, i.e., a score of 5 indicated slight disagreement with the statement whereas 6 indicated slight agreement, allowed for clear interpretation of the data (Bryman 2012). Participants were able to leave a response blank if they preferred (Marshall 2007). Each of the survey questions is reflected within each of the tables presented in our results section. The final survey was pretested for readability, ambiguity, and variability in responses with three MPA managers, and refined accordingly.

A study to enhance the communication and uptake of climate adaptation science could have taken many forms, however, the practicalities of eliciting information from environmental managers across widely distributed agencies and geographies suggested that a structured survey would work best. In this case other methodologies, such as focus group work or workshop techniques, were not practical given geographic constraints.

\section{Survey administration}

The final version of the quantitative survey was administered to Australian MPA managers spanning three Australian management agencies. No researchers were included during this phase of the study. Marine protected area managers were defined as those representing key management agencies, at either the state or federal level of government, responsible for making management/policy decisions in relation to a MPA in Australian waters, as established in Cvitanovic et al. (2013). Australia contains some of the world's most expansive MPA networks spanning tropical, subtropical, and temperate environments managed by multiple organizations across multiple levels of government, making Australia an ideal setting to explore and compare the perceptions of MPA managers.

Individual participants were identified by contacting a senior manager in each agency and asking them to identify suitable participants within their organization to take part in the study (following Cvitanovic et al. 2013). Collectively, 37 individuals across the 3 agencies fit the definition. Individuals were then contacted, information about the research provided, and consent to participate was requested. In total, 30 of the 37 Australian MPA managers agreed to take part in the survey, and on average, these participants had worked within their organization for 79 months (range 5-192 months), and had worked in their current role for 31 months (range 3-84 months). The survey was then administered to the 30 individuals, either face to face or via telephone. Care was taken to ensure that each participant was given the same amount of information about the survey, and a single member of the research team (CC) completed all surveys to ensure consistency.

Data were analyzed with descriptive statistics to assess the sample populations' perceptions about climate change, climate adaptation, and science. We note that there is ongoing discussion in the literature on whether Likert data should be considered as ordinal or interval, with subsequent implications for analyses and reporting. This discussion has largely arisen out of the difficulties 
Table 1. Perceptions of Australian marine protected areas (MPA) decision makers $(n=30)$ about the potential risks of climate change. Scores are based on a Likert scale between 1 and 10, where a score of 1 indicated that the participant strongly disagreed with the statement, whereas a score of 10 meant that the participant strongly agreed with the statement.

\begin{tabular}{|c|c|c|c|c|}
\hline & Mean & $\mathrm{SE}$ & Mode & Range \\
\hline Changes to biodiversity are likely to occur as a result of climate change. & 9.2 & 0.2 & 10 & 3 \\
\hline Species extinctions are likely to occur as a result of climate change. & 9 & 0.2 & 10 & 3 \\
\hline Changes to ecosystem function are likely to occur as a result of climate change. & 9.1 & 0.3 & 10 & 6 \\
\hline Ecosystem collapse is likely to occur as a result of climate change. & 7.9 & 0.3 & 10 & 6 \\
\hline Changes to fisheries resources are likely to occur as a result of climate change. & 8.7 & 0.3 & 10 & 4 \\
\hline Fisheries collapse is likely to occur as a result of climate change. & 6.7 & 0.4 & 8 & 7 \\
\hline $\begin{array}{l}\text { Impacts on the coastal zone (e.g., impacts to coastal infrastructure) are likely to occur as a result } \\
\text { of climate change. }\end{array}$ & 9 & 0.2 & 10 & 4 \\
\hline $\begin{array}{l}\text { Losses from ecosystem goods and services provided to society are likely to occur as a result of } \\
\text { climate change. }\end{array}$ & 8.1 & 0.3 & 10 & 5 \\
\hline Economic hardships are likely to occur as a result of climate change. & 7.6 & 0.4 & 8 & 9 \\
\hline $\begin{array}{l}\text { Important impacts on the government (i.e., loss of public support) are likely to occur as a result of } \\
\text { climate change. }\end{array}$ & 6.8 & 0.4 & 7 & 9 \\
\hline The community will stop valuing the resource as an impact of climate change. & 4.9 & 0.4 & 8 & 8 \\
\hline
\end{tabular}

associated with understanding the ambiguity regarding distance between numerical responses and whether they are interpreted equally by respondents (Göb et al. 2007). To reduce this ambiguity, at the commencement of each set of questions, participants were given linguistic qualifiers, and given that all surveys were done verbally, the opportunity to seek further clarification regarding the scale as needed (Bryman 2012). To ensure a consistent approach in this regard, all surveys were done by a single member of the research team. We report both ordinal and interval statistics, i.e., means and modes, for each statement.

\section{RESULTS}

\section{Perceptions regarding the risks of climate change}

Australian MPA managers have a very strong awareness of the range of threats posed by climate change. Of the 11 potential impacts identified through the scoping study, participants recognized all but 1 as a threat to marine systems. Specifically, Australian MPA managers considered changes to biodiversity, species extinctions, changes to ecosystem function, impacts to the coastal zone, and changes to fisheries resources as the greatest threats facing marine ecosystems (Table 1). We found that participants considered the collapse of ecosystems and fisheries to be of lower risk. Australian MPA managers also identified potential impacts to government, such as the loss of public support, and economic hardships to be of lower risk. The only risk identified through the scoping study that participants did not agree with was that the public would stop valuing the resource as a result of climate change, with many respondents stating their belief that Australian communities would increasingly value local marine ecosystems as a result of climate change (Table 1).

\section{Perceptions regarding the importance, role, and achievability of climate adaptation}

Australian MPA managers considered adaptation to be critically important for managing the risks of climate change (Table 2). In particular, participants agreed that adaptation provides them with options to address the threats associated with climate change. However, $40 \%$ of participants $(n=12)$ agreed that they did not know enough about adaptation to make an informed assessment about its importance.

In general, participants of the study were less certain about the role of adaptation for managing the risks of climate change, with the majority of mean responses falling between 6 and 8, indicating only slight agreement with the statements presented (Table 2). However, participants strongly agreed that the role of adaptation was to allow decision makers to look forward and develop proactive rather than reactive intervention measures, thereby allowing society to cope with alternate and inevitable ecological states. We did find that some participants considered adaptation and mitigation quite similarly, with $33 \%$ of participants $(\mathrm{n}=10)$ scoring $\geq 6$ (Table 2 ).

We also found that Australian MPA managers were optimistic regarding the achievability of adaptation (Table 2). In particular, participants strongly agreed that adaptation would be most achievable when all stakeholders worked together. Importantly, participants recognized that for adaptation to be achievable, people and governance structures must be flexible. However, participants also agreed that the government is a major barrier limiting the achievability of adaptation. Specifically, Australian MPA managers felt that adaptation is not currently achievable because it lacks proper consideration by governments, is not a current priority for governments, and it receives insufficient government funding (Table 2). We also found that many participants did not possess sufficient knowledge about adaptation to make an informed assessment on its achievability, with 14 of the 30 participants agreeing that they did not know enough ( $\geq 6$ ) about adaptation to make an informed assessment on its feasibility (Table 2).

\section{Perceptions regarding science}

Participants of our study acknowledged the importance of science for informing the decision-making process, and strongly agreed that science is a critical source of information for making decisions (Table 3). However, Australian MPA managers also recognized the importance of other forms of knowledge, such as 
Table 2. Perceptions of Australian marine protected areas (MPA) decision makers ( $\mathrm{n}=30$ ) about the importance, role, and achievability of adaptation for managing the risks of climate change. Scores are based on a Likert scale between 1 and 10, where a score of 1 indicated that the participant strongly disagreed with the statement, whereas a score of 10 meant that the participant strongly agreed with the statement.

\begin{tabular}{|c|c|c|c|c|}
\hline & Mean & SE & Mode & Range \\
\hline \multicolumn{5}{|l|}{ Importance of adaptation } \\
\hline Adaptation is critically important for managing the risks of climate change. & 8.4 & 0.4 & 10 & 9 \\
\hline $\begin{array}{l}\text { Adaptation is more important than mitigation in relation to managing the impacts of climate } \\
\text { change. }\end{array}$ & 5.4 & 0.4 & 6 & 9 \\
\hline $\begin{array}{l}\text { In theory adaptation is important, however, there is not enough science to understand the actual } \\
\text { importance of adaptation. }\end{array}$ & 5.6 & 0.4 & 6 & 8 \\
\hline $\begin{array}{l}\text { Adaptation is important because it provides decision makers with options to address the threats } \\
\text { associated with climate change. }\end{array}$ & 7.9 & 0.2 & 8 & 5 \\
\hline $\begin{array}{l}\text { Relative to other threats, the impacts associated with climate change will not become important } \\
\text { until after } 2050 \text {, and therefore adaptation is not important at present. }\end{array}$ & 1.6 & 0.2 & 1 & 4 \\
\hline I don't know enough about adaptation to make an informed assessment on its importance. & 4.6 & 0.5 & 1 & 9 \\
\hline \multicolumn{5}{|l|}{ Role of adaptation } \\
\hline Adaptation allows us to manage the unavoidable. & 6.9 & 0.5 & 8 & 9 \\
\hline Adaptation provides options to decision makers and helps facilitate the uptake of these options. & 7.2 & 0.4 & 8 & 9 \\
\hline $\begin{array}{l}\text { Adaptation provides an alternative baseline/option for managing ecosystems and ecosystem/ } \\
\text { function. }\end{array}$ & 6.8 & 0.3 & 8 & 7 \\
\hline Adaptation provides alternative government structures for managing ecosystems. & 6.2 & 0.4 & 8 & 8 \\
\hline Adaptation provides social, economic, and biophysical outcomes. & 7.7 & 0.2 & 8 & 4 \\
\hline $\begin{array}{l}\text { Using adaptation successfully will allow society to cope with alternate and inevitable ecological } \\
\text { states. }\end{array}$ & 7.9 & 0.4 & 10 & 8 \\
\hline $\begin{array}{l}\text { Adaptation allows us to look forward and develop proactive rather than reactive intervention } \\
\text { measures. }\end{array}$ & 8.3 & 0.3 & 10 & 5 \\
\hline Adaptation is similar to mitigation. & 4.5 & 0.4 & 5 & 8 \\
\hline \multicolumn{5}{|l|}{ Achievability of adaptation } \\
\hline Climate adaptation is not achievable/feasible. & 3 & 0.4 & 2 & 8 \\
\hline Climate adaptation is not achievable/feasible because it is too expensive. & 3.2 & 0.4 & 2 & 9 \\
\hline Climate adaptation is most achievable when it is driven by communities rather than governments. & 6.7 & 0.4 & 9 & 8 \\
\hline $\begin{array}{l}\text { Climate adaptation is not feasible or achievable because it lacks proper consideration by political } \\
\text { figures/governments. }\end{array}$ & 7 & 0.4 & 9 & 8 \\
\hline Climate adaptation is not feasible or achievable because it is not a priority for government. & 7.9 & 0.3 & 8 & 7 \\
\hline $\begin{array}{l}\text { Climate adaptation is not feasible or achievable because it does not receive sufficient funding from } \\
\text { governments. }\end{array}$ & 7.9 & 0.3 & 8 & 5 \\
\hline The achievability of climate adaptation is enhanced when all stakeholders work together. & 9.3 & 0.2 & 10 & 3 \\
\hline Adaptation is only achievable if people and governance structures are flexible. & 8.6 & 0.2 & 10 & 4 \\
\hline Adaptation is more achievable in built environments compared to natural environments. & 5.9 & 0.4 & 5 & 9 \\
\hline There is not enough science to assess whether or not climate adaptation is feasible/achievable. & 4.9 & 0.4 & 7 & 9 \\
\hline I can think of an example of where climate adaptation has already successfully occurred. & 6.7 & 0.6 & 10 & 9 \\
\hline $\begin{array}{l}\text { I don't know enough about climate adaptation to make an informed assessment about its } \\
\text { achievability or feasibility. }\end{array}$ & 5.5 & 0.5 & 8 & 9 \\
\hline
\end{tabular}

community and cultural knowledge; many believing that science is not necessarily more important. Furthermore, we found that not all participants considered science to be less biased than other forms of knowledge, such as community or cultural knowledge.

Australian MPA managers most valued science that provided early warning of impacts, therefore allowing decision makers to be proactive rather than reactive (Table 3). Furthermore, participants considered that the role of science is to provide a strong evidence base for making decisions, which in turn increases the likely success of that decision. Participants also believed that the role of science is to assist them to prioritize management interventions (Table 3).

In relation to the traits that increase the extent to which MPA managers trust science, we found that the science per se was more important than the individual scientists. In particular, trust in science was greatest when there was a strong evidence base on a topic that managers could personally critically evaluate (Table 3 ). The MPA managers also trust science that is impartial and evidenced based, providing realistic examples and/or case studies, and science that is pragmatic in outlining management options that are realistically achievable within the confines of management/policy (Table 3).

Although the reputation of individual scientists may be important, the institution to which they belong and their track record, e.g., citation indices, play a much smaller role in conferring trust (Table 3). Similarly, participants stated that they did not necessarily trust science simply because it was published in a high impact journal, and as such, the impact factor of a journal plays a smaller role in conferring trust in the science. Finally, individual 
Table 3. Perceptions of Australian marine protected areas (MPA) decision makers $(n=30)$ about the role of science in managing the risks of climate change, and the traits that increase trust in science. Scores are based on a Likert scale between 1 and 10, where a score of 1 indicated that the participant strongly disagreed with the statement, whereas a score of 10 meant that the participant strongly agreed with the statement.

\begin{tabular}{|c|c|c|c|c|}
\hline & Mean & SE & Mode & Range \\
\hline \multicolumn{5}{|l|}{ Role of science } \\
\hline Science is the critical source of information for making decisions. & 8.4 & 0.2 & 9 & 5 \\
\hline Science is the most useful source of information as it is robust, tried, and tested. & 8 & 0.2 & 8 & 5 \\
\hline $\begin{array}{l}\text { Science is more important than other forms of knowledge, such as community knowledge } \\
\text { or cultural knowledge. }\end{array}$ & 5.8 & 0.4 & 7 & 8 \\
\hline $\begin{array}{l}\text { Science is less biased than other forms of knowledge, such as community or cultural } \\
\text { knowledge. }\end{array}$ & 6.9 & 0.4 & 8 & 9 \\
\hline $\begin{array}{l}\text { Science allows decision makers to overcome current barriers to successful management } \\
\text { actions (e.g., those associated with scale). }\end{array}$ & 7.2 & 0.4 & 8 & 9 \\
\hline $\begin{array}{l}\text { Science provides a strong evidence base for making decisions, therefore increasing the likely } \\
\text { success of a decision. }\end{array}$ & 8.1 & 0.2 & 9 & 5 \\
\hline Science provides certainty and assurance to decision makers. & 7.5 & 0.3 & 8 & 6 \\
\hline Science allows decision makers to prioritize management interventions. & 8.1 & 0.2 & 8 & 4 \\
\hline $\begin{array}{l}\text { Science can provide early warning of impacts, which allows decision makers to be proactive } \\
\text { rather than reactive. }\end{array}$ & 8.3 & 0.3 & 10 & 7 \\
\hline $\begin{array}{l}\text { Science can help encourage and facilitate flexible and adaptive institutions and governance } \\
\text { arrangements. }\end{array}$ & 7 & 0.4 & 7 & 8 \\
\hline \multicolumn{5}{|l|}{ Trust in science } \\
\hline I trust science when the authors have a good reputation. & 8.1 & 0.3 & 9 & 7 \\
\hline I trust science when the authors belong to a respected institution. & 7 & 0.2 & 6 & 5 \\
\hline I trust science when the authors have a strong track record (i.e., strong citation indices). & 7.3 & 0.2 & 7 & 5 \\
\hline $\begin{array}{l}\text { I trust science when it is published in a high impact scientific journal, e.g., Nature or } \\
\text { Science. }\end{array}$ & 7.3 & 0.4 & 9 & 7 \\
\hline I trust science when it is supported by robust statistical analysis. & 8.2 & 0.4 & 9 & 9 \\
\hline $\begin{array}{l}\text { I trust science when there is a strong depth of evidence on a topic that I can personally } \\
\text { critically evaluate. }\end{array}$ & 9.1 & 0.2 & 10 & 4 \\
\hline $\begin{array}{l}\text { I trust science when it is pragmatic in outlining management options that are realistically } \\
\text { achievable within the confines of policy/management. }\end{array}$ & 8.4 & 0.3 & 9 & 5 \\
\hline I trust science when it is impartial and evidence based with realistic examples/case studies. & 9.1 & 0.2 & 10 & 3 \\
\hline I trust science when the funding organizations are identified. & 7.1 & 0.4 & 7 & 9 \\
\hline I trust science when the funding body is a well respected institution. & 6.5 & 0.4 & 6 & 9 \\
\hline I trust science when scientists can reach consensus among themselves on an issue. & 7.5 & 0.4 & 8 & 9 \\
\hline $\begin{array}{l}\text { I trust science when it is communicated effectively in a 'language' that decision makers can } \\
\text { understand. }\end{array}$ & 7.6 & 0.3 & 8 & 6 \\
\hline $\begin{array}{l}\text { I trust science when the scientists themselves are effective communicators and make an } \\
\text { effort to communicate their research findings through face to face interactions. }\end{array}$ & 7.8 & 0.3 & 8 & 6 \\
\hline I trust science when I know the scientists personally and understand their values. & 6.6 & 0.4 & 6 & 9 \\
\hline
\end{tabular}

rapport between scientists and managers and knowing the values of a scientist do not necessarily confer trust.

\section{DISCUSSION}

Understanding the perceptions of environmental managers is critical to help overcome communication barriers and improve the uptake of science into the decision-making process. We provide a quantitative assessment of the perceptions of MPA managers in relation to the risks of climate change, the importance, role, and achievability of climate adaptation, and the role of science in managing the risks of climate change. Using an Australian case study, we showed that although these MPA managers have a very strong awareness of the range and severity of risks posed by climate change, their understanding of adaptation as an option for managing these risks is less comprehensive. We also found that although these MPA managers view science as critical for informing the decision- making process, it should be considered in context with other knowledge types such as community and cultural knowledge, and be impartial, evidence-based, and pragmatic in outlining policy and management recommendations that are realistically achievable within the confines of management and policy.

\section{The risks of climate change}

Our results show that Australian MPA managers are concerned about a large range of potential effects relating to climate change on biodiversity, species extinctions, and ecosystem function. This is not surprising given the expansive body of literature already documenting and predicting the risk of extinction from climate change (reviewed by Dulvy et al. 2003) and how the declining abundance of individual species can result in changes to ecosystem function (Worm et al. 2006). Similarly, participants identified impacts to the coastal zone as a major risk associated with climate change, a question of particular policy relevance 
(Sutherland et al. 2006), which has been scientifically documented in both Australia (Traill et al. 2011, McAllister et al. 2013) and other parts of the world (Harley et al. 2006), and the subject of high media coverage associated with the increased frequency and severity of extreme weather events.

In comparison, participants considered the collapse of ecosystems and fisheries to be of lesser concern. These findings may also suggest that MPA managers in Australia may be unaware of recent research highlighting the predicted and potential risk of ecosystem collapse associated with climate change (e.g., Smith et al. 2009, Hare et al. 2011). Given the potential importance of ecosystem collapse to society, it is important that the likelihood and consequences of future ecosystem collapses as a result of climate change are demonstrated in the scientific literature and then communicated as a priority to raise awareness among Australian MPA managers.

\section{The importance, role, and achievability of climate adaptation}

Although participating identified adaptation as critically important for managing the risks of climate change, we found high levels of variation in their understanding and awareness regarding the importance, role, and achievability of adaptation. For example, almost half of the participants answered that they did not know enough about adaptation to make an informed assessment on its importance or achievability. Similarly, we found that participants were not confident that there is enough science to assess the achievability of adaptation. These findings suggest that MPA managers in Australia are largely unaware and unfamiliar with the wealth of adaptation science currently available to inform the decision-making process (Webb and Beh 2013) and highlight the need for more effective methods of knowledge transfer.

Several novel methods of knowledge transfer have been identified in the literature to improve information flow among academics and managers. These include the coproduction of knowledge, whereby environmental practitioners actively participate in scientific research programs, allowing them to develop a comprehensive understanding of the research content (Ceccarelli et al. 2011, Hoey et al. 2011, Underwood et al. 2013). Another increasingly recognized approach to improve information flow among academics and environmental practitioners is through the use of knowledge brokers or bridging organizations, i.e., intermediaries that aim to develop relationships and networks with, among, and between producers and users of knowledge, to facilitate the exchange of knowledge throughout this network (Michaels 2009, Meyer 2010, Crona and Parker 2012). Finally, social media has revolutionized opportunities for communication, networking, and idea sharing among producers and users of knowledge and could be used to raise awareness of adaptation science among end users (Thaler et al. 2012).

Our results also suggested that some Australian MPA managers may be unaware of the differences between mitigation and adaptation, with $33 \%$ of participants agreeing that mitigation and adaptation are similar. Although both are important concepts in relation to managing for climate change, the greatest results will be achieved when mitigation and adaptation strategies are designed to complement one another. However, the ways in which they are approached from a policy perspective must be differentiated. This is described by Klein et al. (2005), who identified three primary differences between mitigation and adaptation, which influence policy and management drivers and outcomes: (1) the spatial and temporal scales in which they operate; (2) the extent to which their costs, and in particular, benefits can be determined; and (3) the actors and types of policies involved in their implementation. To adequately develop both mitigation and adaptation responses, Australian MPA managers, and any individuals involved in environmental decision making, must have a strong understanding of each concept and the implications of both. Accordingly, scientists must ensure that they use the terms consistently and correctly through all communication activities and make clear to audiences the differences of each concept, both in terms of their definitions and also their policy and management implications. Furthermore, scientists must also show environmental managers that the two concepts are not mutually exclusive, but indeed, the greatest results will be achieved when mitigation and adaptation policies are designed to complement one another (Laukkonen et al. 2009).

Participants also agreed that the government is a major barrier currently hindering the achievability of adaptation activities. These findings are concerning because it has been suggested that perceptions of barriers can limit action just as strongly as actual barriers, even in cases in which both sufficient capacity and resources to adapt exist (Adger et al. 2007). Similar findings have also been reported in the United States, where it was found that internal barriers, such as unclear mandates from senior staff, combined with bureaucratic rules and procedures, were perceived by government officials to be a significant barrier (Jantarasami et al. 2010). Accordingly, to overcome such barriers, government agencies should establish a clear agency mandate in relation to climate adaptation and give adequate resources to the implementation of the mandate, so that staff feel empowered to implement climate adaptation initiatives.

\section{The role and trust of science}

The importance of integrating science into the decision-making process for environmental management is widely accepted, and participants confirmed this, identifying science as a critical source of information when making decisions. However, we found that Australian MPA managers do not consider science more important than other forms of knowledge, such as community or cultural knowledge. Indeed, the past decade has seen a rapidly growing interest in the potential role of other knowledge forms to inform the decision-making process broadly across natural resource management arenas (Aswani and Hamilton 2004), but also specifically in relation to climate adaptation (Salick and Ross 2009, Naess 2013). This is not surprising given (1) the importance of local knowledge for illustrating to local communities the consequences of climate change and (2) the promotion of culturally appropriate adaptation policies to improve community acceptance (Reid et al. 2009, Gearheard et al. 2010, Boillat and Berkes 2013). However, as with science, the integration of other knowledge forms into policies and strategies for adaptation has been slow, at both national and international levels (Naess 2013).

These findings have important implications for the communication and uptake of science into environmental decisions both in Australia and internationally. Specifically, these findings suggest that for science to be most influential and relevant for environmental managers, scientists will need to incorporate 
and consider a range of knowledge sources when developing management and/or policy recommendations. One way to achieve this would be through the establishment of multidisciplinary research teams, and specifically the inclusion of social scientists on research teams, to elucidate social perspectives in relation to the biophysical research being undertaken. However, traditionally, the integration of social and ecological sciences has been difficult and the majority of research has been undertaken within the boundaries of a single discipline, neglecting the relationships between ecological and social systems (Fox et al. 2006). This is clearly no longer tenable, and greater efforts to incorporate social dimensions into biophysical research are needed (Redman et al. 2004, Frusher et al. 2014).

We also found that Australian MPA managers most valued science that provided early warning of impacts, thus allowing managers to be proactive rather than reactive. It is therefore critical that Australian MPA managers and decision makers more broadly have access to research in a timely manner. However, several studies have shown that it takes considerable time for results to be published following the completion of data collation (Kareiva et al. 2002, Fazey et al. 2005). Consequently, effective knowledge transfer methods, which promote faster communication of science, i.e., knowledge brokers, boundary organizations, and the coproduction of knowledge, will become increasingly important modes of transferring information.

Furthermore, participants considered that the role of science is to provide a strong evidence base for making decisions and to assist them to prioritize management interventions. Given this, it is not surprising that participants trust science most when there is a strong depth of knowledge on a topic that they can personally critically evaluate. However, the process of locating, accessing, and reading primary literature may be too time consuming for environmental managers to undertake in addition to their daily responsibilities (Pullin et al. 2004). As such, scientists and research organizations could invest greater effort in the development of systematic reviews on particular topics, to provide the necessary information to decision makers in an easily digestible form that also provides links to the individual studies and greater detail if needed (Cook et al. 2013). A similar approach has already proven to be successful in the medical sciences and could be adopted by the conservation and resource management sciences (Fazey et al. 2004).

Participants trust science when it is impartial, evidence based, and pragmatic in outlining policy and management recommendations, which are realistically achievable within the confines of management and policy. These findings have several important implications for the ways in which science is produced and communicated. First, scientists must ensure that any bias is fully disclosed because decision makers do not consider science less biased than other knowledge forms, and support from certain funding bodies can influence trust (Krimsky 2013). Second, these findings suggest that Australian MPA managers are most likely to trust science, and hence incorporate it into the decision-making process, when it is grounded by evidence. As such, conceptual and theoretical research is less likely to influence the decision-making process (Fawcett and Higginson 2012), and concepts need to be firmly grounded through relevant and realistic case studies. Third, scientists must develop recommendations that are realistically achievable within the confines of existing management and policy. As such, scientists need to understand and take into account the policy context of environmental issues and understand trade-offs between the best-case scenario and what is actually achievable. By developing recommendations that take policy constraints into account, they are more likely to influence the decision-making process.

Finally, our results confirm that science is not trusted by decision makers simply because of the journal in which it is published, nor are the citation indices of an individual scientist. Such metrics, however, continue to drive academia, and have led governments, research authorities, and university administrators to assess research performance using indices that allow comparisons and ranking (Panaretos and Malesios 2009). Indices, such as the journal impact factor, or h-index, provide a simple and quantitative metric of academic performance, however, they do not indicate how relevant or useful the science is to end users (Adler and Harzing 2009, Harzing and van der Wal 2009). To overcome this, we suggest that conservation sciences transition toward new approaches to measure impact, whereby, impact would incorporate the uptake of the research by end users (Weiss 2007). Under this approach, the impact of science and scientists is not measured by the number of publications they produce, nor the number of citations they receive, but the extent to which they work with end users to ensure improved knowledge flow and integration. These new metrics will be difficult to quantify and must be complimented by new reward systems for scientists, which take such activities into account for the purposes of assessing grant applications, merit-based promotions or similar. Ultimately, however, a transition in this direction would result in a more concerted effort from scientists to engage and work with end users, thereby improving the uptake of science into the decision-making process.

\section{Responses to this article can be read online at: http://www.ecologyandsociety.org/issues/responses. $\mathrm{php} / 7019$}

\section{Acknowledgments:}

We thank all participants who took part in this study. We also thank C. James, M. Howden, R. Wise, R. Gorddard, J. Goldberg, K. Waples, and $K$. Cvitanovic for helpful comments and insightful discussion that improved the manuscript. We also thank the two anonymous reviewers and the editor for their constructive comments and suggestions on earlier versions of this manuscript. Financial support was provided by the CSIRO Climate Adaptation Flagship.

\section{LITERATURE CITED}

Adger, W. N. S., M. M. Q. Agrawala, C. Mirza, K. Conde, J. O'Brien, R. Pulhin, B. S. Pulwarty, B. Smit, and K. Takahashi. 2007. Assessment of adaptation practices, options, constraints and capacity. Pages 717-743 in M. L. Parry, O. F. Canziani, J. P. Palutikof, P. J. van der Linden, and C. E. Hanson, editors. Climate change 2007: impacts, adaptation and vulnerability. Contribution of the Working Group II to the Fourth Assessment report of the Intergovernmental Panel on Climate Change. Intergovernmental 
Panel on Climate Change, Cambridge University Press, Cambridge, UK. [online] URL: http://www.ipcc.ch/pdf/ assessment-report/ar4/wg2/ar4-wg2-chapter17.pdf

Adler, N. J., and A.-W. Harzing. 2009. When knowledge wins: transcending the sense and nonsense of academic rankings. Academy of Management, Learning and Education 8:72-95. http:// dx.doi.org/10.5465/AMLE.2009.37012181

Aswani, S., and R. J. Hamilton. 2004. Integrating indigenous ecological knowledge and customary sea tenure with marine and social science for conservation of bumphead parrotfish (Bolbometapon muricatum) in the Roviana Lagoon, Solomon Islands. Environmental Conservation 31:69-83. http://dx.doi. org/10.1017/S037689290400116X

Bassett, T. J., and C. Fogelman. 2013. Déjà vu or something new? The adaptation concept in the climate change literature. Geoforum 48:42-53. http://dx.doi.org/10.1016/j.geoforum.2013.04.010

Beger, M., R. Babcock, D. J. Booth, D. Bucher, S. A. Condie, B. Creese, C. Cvitanovic, S. J. Dalton, P. Harrison, A. Hoey, A. Jordan, J. Loder, H. Malcolm, S. W. Purcell, C. Roelfsma, P. Sachs, S. D. A. Smith, B. Sommer, R. Stuart-Smith, D. Thomson, C. C. Wallace, M. Zann, and J. M. Pandolfi. 2011. Research challenges to improve the management and conservation of subtropical reefs to tackle climate change threats. Ecological Management and Restoration 12(1):e7-e10. http://dx.doi.org/10.1111/j.1442-8903.2011.00573. $\underline{\mathrm{X}}$

Bellard, C., C. Bertelsmeier, P. Leadley, W. Thuiller, and F. Courchamp. 2012. Impacts of climate change on the future of biodiversity. Ecology Letters 15:365-377. http://dx.doi.org/10.1111/ j.1461-0248.2011.01736.x

Boillat, S., and F. Berkes. 2013. Perception and interpretation of climate change among Quechua farmers of Bolivia: indigenous knowledge as a resource for adaptive capacity. Ecology and Society 18(4): 21. http://dx.doi.org/10.5751/ES-05894-180421

Boissière, M., B. Locatelli, D. Sheil, M. Padmanaba, and E. Sadjudin. 2013. Local perceptions of climate variability and change in tropical forests of Papua, Indonesia. Ecology and Society 18(4): 13. http://dx.doi.org/10.5751/ES-05822-180413

Briggs, S. V. 2006. Integrating policy and science in natural resources: why so difficult? Ecological Management and Restoration 7:37-39. http://dx.doi.org/10.1111/j.1442-8903.2006.00245. $\underline{\mathrm{X}}$

Bryman A. 2012. Social research methods. Oxford University Press, Oxford, UK.

Ceccarelli, D. M., Z. T. Richards, M. S. Pratchett, and C. Cvitanovic. 2011. Rapid increase in coral cover on an isolated coral reef, the Ashmore Reef National Nature Reserve, northwestern Australia. Marine and Freshwater Research 62:1214-1220. http://dx.doi.org/10.1071/MF11013

Center for Research on Environmental Decisions (CRED). 2009. The psychology of climate change communication: a guide for scientists, journalist, educators, political aides and the interested public. Center for Research on Environmental Decisions, New York, New York, USA. [online] URL: http://guide.cred. columbia.edu/
Cook, C. N., M. Hockings, and R. W. Carter. 2010. Conservation in the dark? The information used to support management decisions. Frontiers in Ecology and the Environment 8:181-186. http://dx.doi.org/10.1890/090020

Cook, C. N., H. P. Possingham, and R. A. Fuller. 2013. Contribution of systematic reviews to management decisions. Conservation Biology 27:902-915. http://dx.doi.org/10.1111/ cobi. 12114

Crona, B. I., and J. N. Parker. 2012. Learning in support of governance: theories, methods, and a framework to assess how bridging organizations contribute to adaptive resource governance. Ecology and Society 17(1): 32. http://dx.doi. org/10.5751/ES-04534-170132

Cvitanovic, C., C. J. Fulton, S. K. Wilson, L. van Kerkhoff, I. L. Cripps, and N. Muthiga. 2014. Utility of primary scientific literature to environmental managers: an international case study on coral-dominated marine protected areas. Ocean and Coastal Management 102:72-78. http://dx.doi.org/10.1016/j.

ocecoaman.2014.09.003

Cvitanovic, C., S. K. Wilson, C. J. Fulton, G. R. Almany, P. Anderson, R. C. Babcock, N. C. Ban, R. J. Beeden, M. Beger, J. Cinner, K. Dobbs, L. S. Evans, A. Farnham, K. J. Friedman, K. Gale, W. Gladstone, Q. Grafton, N. A. J. Graham, S. Gudge, P. L. Harrison, T. H. Holmes, N. Johnstone, G. P. Jones, A. Jordan, A. J. Kendrick, C. J. Klein, L. R. Little, H. A. Malcolm, D. Morris, H. P. Possingham, J. Prescott, R. L. Pressey, G. A. Skilleter, C. Simpson, K. Waples, D. Wilson, and D. H. Williamson. 2013. Critical research needs for managing coral reef marine protected areas: perspectives of academics and managers. Journal of Environmental Management 114:84-91. http://dx.doi.org/10.1016/ j.jenvman.2012.10.051

Dulvy, N. K., Y. Sadovy, and J. D. Reynolds. 2003. Extinction vulnerability in marine populations. Fish and Fisheries 4:25-64. http://dx.doi.org/10.1046/j.1467-2979.2003.00105.x

Fawcett, T. W., and A. D. Higginson. 2012. Heavy use of equations impedes communication among biologists. Proceedings of the National Academy of Sciences 109(29):11735-11739. http://dx. doi.org/10.1073/pnas.1205259109

Fazey, I., J. G. Salisbury, D. B. Lindenmayer, D. Maindonald, and R. Douglas. 2004. Can methods applied in medicine be used to summarize and disseminate conservation research? Environmental Conservation 31(3):190-198. http://dx.doi.org/10.1017/ $\underline{\mathrm{S} 0376892904001560}$

Fazey, I., J. Fischer, and D. B. Lindenmayer. 2005. What do conservation biologist publish? Biological Conservation 124:63-73. http://dx.doi.org/10.1016/j.biocon.2005.01.013

Fink A. 2013. How to conduct surveys: a step-by-step guide. Sage, Thousand Oaks, California, USA.

Fox, H. E., C. Christian, J. G. Nordby, O. R. W. Pergams, G. D. Peterson, and C. R. Pyke. 2006. Perceived barrier to integrating social science and conservation. Conservation Biology 20:1817-1820. http://dx.doi.org/10.1111/j.1523-1739.2006.00598. $\underline{\mathrm{X}}$ 
Frusher, S. D., A. J. Hobday, S. M. Jennings, C. Crighton, D. D’Silva, G. T. Pecl, M. Haward, N. J. Holbrook, M. Nursey-Bray, G. T. Pecl, and E. I. van Putten. 2014. The short history of research in a marine climate change hotspot - from anecdote to adaptation in south-east Australia. Reviews in Fish Biology and Fisheries 24:593-611. http://dx.doi.org/10.1007/s11160-013-9325-7

Gearheard, S., M. Pocernich, R. Stewart, J. Sanguya, and H. P. Huntington. 2010. Linking Inuit knowledge and meteorological station observations to understand changing wind patterns at Clyde River, Nunavut. Climate Change 100:267-294. http://dx. doi.org/10.1007/s10584-009-9587-1

Göb, R., C. McCollin, and M. Fernanda Ramalhoto. 2007. Ordinal methodology in the analysis of Likert scales. Quality and Quantity 41:601-626. http://dx.doi.org/10.1007/s11135-007-9089$\underline{\mathrm{Z}}$

Graham, N. A. J., T. D. Ainsworth, A. H. Baird, N. C. Ban, L. K. Bay, J. E. Cinner, D. M. De Freitas, G. Diaz-Pulido, M. Dornelas, S. R. Dunn, P. I. J. Fidelman, S. Foret, T. C. Good, J. Kool, J. Mellela, L. Penin, M. S. Pratchett, and D. H. Williamson. 2011. From microbes to people: tractable benefits of no-take areas for coral reefs. Oceanography and Marine Biology: An Annual Review 49:105-136. http://dx.doi.org/10.1201/b11009-4

Hamm, J. A., L. M. Pytlik Zillig, M. N. Herian, A. J. Tomkins, H. Dietrich, and S. Michaels. 2013. Trust and intention to comply with a water allocation decision: the moderating roles of knowledge and consistency. Ecology and Society 18(4): 49. http:// dx.doi.org/10.5751/ES-05849-180449

Hare, W. L., W. Cramer, M. Schaeffer, A. Battaglini, and C. C. Jaeger. 2011. Climate hotspots: key vulnerable regions, climate change and limits to warming. Regional Environmental Change 11(1):S1-S13. http://dx.doi.org/10.1007/s10113-010-0195-4

Harley, C. D. G., A. R. Hughes, K. M. Hultgren, B. G. Miner, C. J. B. Sorte, C. S. Thornber, L. F. Rodriguez, L. Tomanek, and S. L. Williams. 2006. The impacts of climate change on coastal marine systems. Ecology Letters 9:228-241. http://dx.doi. org/10.1111/j.1461-0248.2005.00871.X

Harzing, A. W., and R. van der Wal. 2009. A Google Scholar hindex for journals: an alternative metric to measure journal impact in economics and business. Journal of the American Society for Information Science and Technology 60:41-46. http://dx.doi. org/10.1002/asi.20953

Hoey, A. S., M. S. Pratchett, and C. Cvitanovic. 2011. High macroalgal cover and low Coral recruitment undermines the potential resilience of the world's southernmost coral reef assemblages. PLoS One 6(10):e25824. http://dx.doi.org/10.1371/ journal.pone.0025824

Jantarasami, L. C., J. J. Lawler, and C. W. Thomas. 2010. Institutional barriers to climate change adaptation in U.S. National Parks and Forests. Ecology and Society 15(4): 33. [online] URL: http://www.ecologyandsociety.org/vol15/iss4/art33/

Kahan, D. M., E. Peters, M. Wittlin, P. Slovic, L. L. Ouellette, D. Braman, and G. Mandel. 2012. The polarizing impact of science literacy and numeracy on perceived climate change risks. Nature Climate Change 2:732-735. http://dx.doi.org/10.1038/nclimate1547
Kareiva, P., M. Marvier, S. West, and J. Hornisher. 2002. Slowmoving journals hinder conservation efforts. Nature 420:15. http://dx.doi.org/10.1038/420015a

Klein, R. J. T., E. L. F. Schipper, and S. Dessai. 2005. Integrating mitigation and adaptation into climate and development policy: three research questions. Environmental Science and Policy 8:579-588. http://dx.doi.org/10.1016/j.envsci.2005.06.010

Krimsky, S. 2013. Do financial conflicts of interest bias research? An inquiry into the "funding effect" hypothesis. Science, Technology, and Human Values 38:566-587. http://dx.doi. org/10.1177/0162243912456271

Laukkonen, J., P. K. Blanco, J. Lenhart, M. Keiner, B. Cavric, and C. Kinuthia-Njenga. 2009. Combining climate change adaptation and mitigation measures at the local level. Habitat International 33:287-292. http://dx.doi.org/10.1016/j.habitatint.2008.10.003

Leviston, Z., and I. Walker. 2012. Beliefs and denials about climate change: an Australian perspective. Ecopsychology 4:277285. http://dx.doi.org/10.1089/eco.2012.0051

Longstaff, P. H., and S.-U. Yang. 2008. Communication management and trust: their role in building resilience to "surprises" such as natural disasters, pandemic flu, and terrorism. Ecology and Society 13(1): 3. [online] URL: http://www. ecologyandsociety.org/vol13/iss1/art3/

Marshall, N. A. 2007. Can policy perception influence social resilience to policy change? Fisheries Research 86:216-227. http:// dx.doi.org/10.1016/j.fishres.2007.06.008

Marshall, N. A., R. C. Tobin, P.A. Marshall, M. Gooch, and A. J. Hobday. 2013. Social vulnerability of marine resource users to extreme weather events. Ecosystems 16:797-809. http://dx.doi. org/10.1007/s10021-013-9651-6

McAllister, R. R. J., T. F. Smith, C. A. Lovelock, D. Low Choy, A. J. Ash, and J. McDonald. 2014. Adapting to climate change in South East Queensland, Australia. Regional Environmental Change 14:429-433.http://dx.doi.org/10.1007/s10113-013-0505-8

Meyer, M. 2010. The rise of the knowledge broker. Science Communication 32:118-127. http://dx.doi.org/10.1177/1075547009359797

Michaels, S. 2009. Matching knowledge brokering strategies to environmental policy problems and settings. Environmental Science and Policy I2:994-1011. http://dx.doi.org/10.1016/j. envsci.2009.05.002

Morton, S. R., O. Hoegh-Guldberg, D. B. Lindenmayer, M. Harriss Olson, L. Hughes, M. T. McCulloch, S. McIntyre, H. A. Nix, S. M. Prober, D. A. Saunders, A. N. Andersen, M. A. Burgman, E. C. Lefroy, W. M. Lonsdale, I. Lowe, A. J. McMichael, J. S. Parslow, W. Steffen, J. E. Williams, and J. C. Z. Woinarski. 2009. The big ecological questions inhibiting effective environmental management in Australia. Austral Ecology 34:1-9. http://dx.doi.org/10.1111/j.1442-9993.2008.01938.x

Naess, L. O. 2013. The role of local knowledge in adaptation to climate change. WIREs Climate Change 4:99-106. http://dx.doi. org/10.1002/wcc. 204

Ormerod, S. J., N. D. Barlow, E. J. P. Marshall, and G. Kerby. 2002. The uptake of applied ecology. Journal of Applied Ecology 39:1-7. http://dx.doi.org/10.1046/j.0021-8901.2001.00705.x 
Panaretos, J., and C. Malesios. 2009. Assessing scientific research performance and impact with single indices. Scientometrics 81:635-670. http://dx.doi.org/10.1007/s11192-008-2174-9

Pereira, H. M., P. W. Leadley, V. Proença, R. Alkemade, J. P. W. Scharlemann, J. F. Fernandez-Manjarrés, M. B Araújo, P. Balvanera, R. Biggs, W. W. L. Cheung, L. Chini, H. D. Cooper, E. L. Gilman, S. Guénette, G. C. Hurtt, H. P. Huntington, G. M. Mace, T. Oberdorff, C. Revenga, P. Rodrigues, R. J. Scholes, U. R. Sumaila, and M. Walpole. 2010. Scenarios for global biodiversity in the 21st century. Science 330:1496-1501. http://dx. doi.org/10.1126/science.1196624

Policansky, D. 1998. Science and decision making for water resources. Ecological Applications 8:610-618. http://dx.doi. org/10.1890/1051-0761(1998)008[0610:SADMFW]2.0.CO;2

Possingham, H. 2009. Dealing with 'The Great Divide': a tacit assumption or a universal truth? Decision Point 28:2-3.

Pouyat, R. V. 1999. Science and environmental policy - making them compatible. Bioscience 49:281-286. http://dx.doi. org/10.2307/1313611

Pullin, A. S., T. M. Knight, D. A. Stone, and K. Charman. 2004. Do conservation managers use scientific evidence to support their decision-making? Biological Conservation 119:245-252. http://dx. doi.org/10.1016/j.biocon.2003.11.007

Redman, C. L., J. M. Grove, and L. H. Kuby. 2004. Integrating social science into the long-term ecological research (LTER) network: social dimensions of ecological change and ecological dimensions of social change. Ecosystems 7:161-171. http://dx.doi. org/10.1007/s10021-003-0215-Z

Reid, H., M. Alam, R. Berger, T. Cannon, and A. Milligan, editors. 2009. Community-based adaptation to climate change, participatory learning and action. International Institute for Environment and Development, London, UK.

Roux, D. J., K. H. Rogers, H. C. Biggs, P. J. Ashton, and A. Sergeant. 2006. Bridging the science-management divide: moving from unidirectional knowledge transfer to knowledge interfacing and sharing. Ecology and Society 11(1): 4. [online] URL: http:// www.ecologyandsociety.org/vol11/iss1/art4/

Salick, J., and N. Ross. 2009. Traditional peoples and climate change. Global Environmental Change 19:137-139. http://dx.doi. org/10.1016/j.gloenvcha.2009.01.004

Smith, J. B., S. H. Schneider, M. Oppenheimer, G. W. Yohe, W. Hare, M. D. Mastrandrea, A. Patwardhan, I. Burton, J. CorfeeMorlot, C. H. D. Magadza, H.-M. Füssel, A. B. Pittock, A. Rahman, A. Suarez, and J.-P. van Ypersele. 2009. Assessing dangerous climate change through an update of the Intergovernmental Panel on Climate Change (IPCC) "reasons for concern." Proceedings of the National Academy of Sciences 106 (11):4133-4137. http://dx.doi.org/10.1073/pnas.0812355106

Sutherland, W. J., A. S. Pullin, P. M. Dolman, and T. M. Knight. 2004. The need for evidence-based conservation. Trends in Ecology and Evolution 19(6):305-308. http://dx.doi.org/10.1016/j. tree.2004.03.018

Sutherland, W. J., S. Armstrong-Brown, P. R. Armsworth, B. Tom, J. Brickland, C. D. Campbell, D. E. Chamberlain, A. I. Cooke,
N. K. Dulvy, N. R. Dusic, M. Fitton, R. P. Freckleton, H. C. J. Godfray, N. Grout, H. J. Harvey, C. Hedley, J. J. Hopkins, N. B. Kift, J. Kirby, W. E. Kunin, D. W. MacDonald, B. Marker, M. Naura, A. R. Neale, T. Oliver, D. Osborn, A. S. Pullin, M. E. A. Shardlow, D. A. Showler, P. L. Smith, R. J. Smithers, J.-L. Solandt, J. Spencer, C. J. Spray, C. D. Thomas, J. Thompson, S. E. Webb, D. W. Yalden, and A. R. Watkinson. 2006. The identification of 100 ecological questions of high policy relevance in the UK. Journal of Applied Ecology 43:617-627. http://dx.doi.org/10.1111/ j.1365-2664.2006.01188.x

Thaler, A. D., K. A. Zelnio, A. Freitag, R. MacPherson, D. Shiffman, H. Bik, M. C. Goldstein, and C. McClain. 2012. Digital environmentalism: tools and strategies for the evolving online ecosystem. Pages 364-373 in D. R. Gallagher, editor. Environmental leadership: a reference handbook. Sage, Thousand Oaks, California, USA. http://dx.doi.org/10.4135/9781452218601. $\underline{\text { n39 }}$

Tomlinson, M., and R. Davis. 2010. Integrating aquatic science and policy for improved water management in Australia. Marine and Freshwater Research 61:808-813. http://dx.doi.org/10.1071/ MF09224

Traill, L. W., K. Perhans, C. E. Lovelock, A. Prohaska, S. McFallan, J. R. Rhodes, and K. A. Wilson. 2011. Managing for change: wetland transitions under sea-level rise and outcomes for threatened species. Diversity and Distribution 17(6):1225-1233. http://dx.doi.org/10.1111/j.1472-4642.2011.00807.x

Underwood, J. N., S. K. Wilson, L. Ludgerus, and R. D. Evans. 2013. Integrating connectivity science and spatial conservation management of coral reefs in north-west Australia. Journal for Nature Conservation 21:163-172. http://dx.doi.org/10.1016/j. inc.2012.12.001

Webb, R., and J. Beh. 2013. Leading adaptation practices and support strategies for Australia: an international and Australian review of products and tools. National Climate Change Adaptation Research Facility, Gold Coast, Queensland, Australia. [online] URL: http://www.nccarf.edu.au/publications/leading-adaptationpractices-and-support-strategies

Weber, J. R., and C. S. Word. 2001. The communication process as evaluative context: what do non-scientists hear when scientists speak? BioScience 51:487-495. http://dx.doi.org/10.1641/0006-3568 (2001)051[0487:TCPAEC]2.0.CO;2

Weiss, A. P. 2007. Measuring the impact of medical research: moving from outputs to outcomes. American Journal of Psychiatry 164:206-214.

Worm, B., E. B. Barbier, N. Beaumont, J. E. Duffy, C. Folke, B. S. Halpern, J. B. C. Jackson, H. K. Lotze, F. Micheli, S. R. Palumbi, E. Sala, K. A. Selkoe, J. J. Stachowicz, and R. Watson. 2006. Impacts of biodiversity loss on ocean ecosystem services. Science 314:787-790. http://dx.doi.org/10.1126/science.1132294 